\title{
The Influence of Individual Characteristics on Auditors' Intention to Report Errors
}

\author{
Arezoo Aghaei Chadegani, Zakiah Muhammaddun Mohamed, and Takiah Mohd Iskandar
}

\begin{abstract}
Reporting detected errors is an important ethical behaviour of auditors which is one dimension of the quality of auditors' work. The main objective of this study is to investigate the effects of auditors' individual characteristics including personality type and locus of control on auditors' intention to report errors. Data are collected by distributing 1000 mail questionnaires among senior auditors in Malaysia. Applying multiple regression analysis, the results reveal that there is a significant and positive relationship between auditors' individual characteristics and their intention to report errors. In fact, research findings indicate that auditors with personality type $A$ and internal locus of control have more intention to report errors than auditors with type $B$ and external locus of control.
\end{abstract}

Index Terms-Behavioural intention, reporting errors, individual characteristics, personality type, locus of control.

\section{INTRODUCTION}

The results of National Business Ethics survey (2007) emphasized that unethical behaviour of auditors is a serious problem in auditing profession and the quality of auditors' work. Unethical behaviour of auditors resulted in high-profile financial scandals and business failure, loss of reputation and litigation costs [1]. Many blamed external auditors for failing to report errors that led to these failures [2]. Therefore, researchers try to determine influencing factors on auditors' behavioural intention to increase their intention to act ethically. Based on theory of planned behaviour (TPB), auditors' behavioural intention is determined by attitude toward behaviour and perceived behavioural control as individual factors [3]. Moreover, according to Financial Reporting Council (2008), individual characteristics as well as auditors' personality are the key drivers in determining auditors' behavioural intention and the quality of their work. Although, there are some studies on quality audit which focused on the relationship between individual characteristics and reduced audit quality behaviours, but they have not examined the effect of these variables on auditors' behavioural intention. This study aimed to fill this gap by investigating the effect of individual characteristics including personality type and locus of control on auditors' intention to report errors. Therefore, the main research objective of this study is to examine the effect of auditors' personality type and locus of control on auditors' intention to report errors.

Manuscript received December 20, 2013; revised February 18, 2014

The authors are with the Department of Accounting, Faculty of Economic and Management, University Kebangsaan Malaysia (UKM), Malaysia (e-mail: arezooaghaie2001@yahoo.com,zmm@ukm.my, takiah@ukm.my).
In order to investigate the effect of individual characteristics on auditors' intention to report errors, the research questionnaires are distributed among 1000 senior auditors in Malaysia and 174 completed questionnaires are received. The results show that there is a significant relationship between auditors' individual characteristics and their intention to report errors. This study contributes to quality audit studies in individual level by investigating the effect of auditors' personality type and locus of control on auditors' intention to report errors. In fact, the quality of auditors' work is measured by auditors' intention to report errors for the first time.

\section{LITERATURE REVIEW AND HYPOTHESES DEVELOPMENT}

Auditors' behaviour is reflective of his personality and individual characteristics when performing audit service [4]. Reference [5] argue that more ethical oriented individuals are more motivated in their intention to behave ethically than less ethical oriented people. Therefore, individual characteristics of auditors have a main role in determining the quality of their work through influencing their decision making and behavioural intention [6]. Individual characteristics have been measured using different variables in various auditing studies. These variables are auditor's ethical reasoning [7], goal orientation [8], professional scepticism [9], auditor's virtue [10], locus of control [11] and personality type [12].

According to reference [13] personality type behaviour and locus of control are two most exhaustively researched personality constructs that is related to ethical behavioural intention. Theory of planned behaviour also suggests that auditors' behavioural intention is determined by auditors' perceived behavioural control and attitude towards behaviour [3]. Perceived behavioural control refers to individuals' perception about having control over the behaviour [14]. Reference [15] argues that auditors' perception about having control over their behaviours refers to individuals' locus of control. Attitude towards behaviour also refers to individuals' common feelings about behaviour and their evaluation about the outcomes [16]. Reference [14] argues that auditors' ethical decision making and behavioural intention are influenced by personality type which represents individuals' ethical orientation. While, our dependent variable is auditor's behavioural intention to report errors, locus of control and personality type which associated with auditor's ethical behavioural intention are chosen as an individual characteristics.

\section{A. Personality Type and Intention to Report Errors}

Based on personality type theory, individuals are categorized into two groups contrasting type of personality; 
high strong type A and easy going type B. Type A individuals are constantly striving to attain material things or achievements in the shortest period of time. But, Type B personalities may be more imaginative, creative and philosophical. Reference [2] mention that individual with type A personality are more competitive, aggressive, ethical oriented and having more commitment to work than individuals with type B personality. Reference [17] believes that these characteristics may have implications for behavioural intention and quality audit literature.

Research in business ethics has shown that personality type A is directly related to individuals' ethical orientation [18]. As reporting errors and misstatement and quality of auditors' work involve ethical decision making, personality type could be affect auditors' intention to report errors and the quality of auditors' work. Reference [18] investigates the relationship between Machiavellianism and type A personality and ethical orientation. They found that Machiavellians tend to have type a personalities but tend to be less ethically-oriented. They conclude that type A personalities are more ethically-oriented than type $B$ personalities.

Reference [19] argues that personality type A/B is found to correlate to ethical sensitivity and decision making such as reporting unethical actions. He found that individuals scoring high in type a behaviour are less likely to engage in unethical behaviours. Reference [2] believes that as personality type was confirmed in prior studies to be associated with ethical orientation, it may have considerable implication in regards to quality of auditor's work. For instance, if individual have more ethical orientation, they would be more likely to report errors and increase the quality of their work. He investigates the relationship between auditors' personality type and their intention to involve in reduced audit quality behaviours. $\mathrm{He}$ concludes that auditors with type A personality are less likely to engage in reduced audit quality behaviours and unethical actions. Therefore, it is appropriate to hypothesis that auditors with type A personality may have more intention to report errors than type Bs and increase quality of audit work because they are more ethical oriented. Thus, the first and second research hypotheses are:

$\mathrm{H}_{1}$ : There is a positive and significant relationship between auditors' personality type and auditors' intention to report errors.

$\mathrm{H}_{2}$ : Auditors with type A personality have more intention to report errors than auditors with type B personality.

\section{B. Locus of Control and Intention to Report Errors}

Another personality trait which affects the auditor's behaviour is an individual's locus of control which is also known as self-evaluation behaviour [20]. Based on locus of control theory individuals are classified as either internals or externals [21]. Individuals who think that events which occur in their lives are consequence of their own personality, behaviour or efforts are internals, whereas individual who believe events are a function of external power beyond their control or manipulation are externals [13]. Reference [22] mention that internals are more proactive and goal oriented and believe that they can influence the outcome of judgment or decision process directly. Although, externals are more passive and prefer structured situation, they believe other factors or aspect of the situation determine the outcome. Internals show higher job motivation [23], more organizational commitment [24] and high ethical orientation [18]. On the other hand, externals believe that outcomes are more attributable to superior decisions and peers' behaviour or the occurrence of luck and chance. Therefore, instead of being in control, they are being controlled by environment [22]. Prior studies have shown that individuals with internal locus of control are more likely to take responsibility for the consequences of ethical/ unethical behaviour and less likely to rely on external forces comparing internals [15].

Locus of control (LOC) clarifies individual's perceptions about relationship between their actions and outcomes [25]. Reference [26] states that locus of control is an individual characteristics that measure the extent to which people believe they are responsible for the consequences of their behaviour, intentions and outcomes. Prior studies have shown that when internals accept a position with a firm they tend to have a higher commitment to the firm relative to externals. Committed employees should work harder, remain with organization and contribute more effectively to an organization [27]. Reference [27] suggests higher committed employees perform better than less committed ones. Therefore, auditors with internal locus of control have higher level of organizational commitment and more intention to report errors and increase quality of audit service [28]. On the other hand, auditor's intention to report errors and misstatement is related to ethical decision making and their ability to resist of clients temptation. Reference [29] suggests since externals rely on fate, luck and chance they are more likely to have intention to behave unethically.

Reference [15] investigated whistle blowing intention among managers, using locus of control within the context of theory of planned behaviour. He found that managers with internal locus of control are more likely to blow the whistle and act ethically compared to those with external locus of control. Therefore, it is predicted that there is a positive relationship between internal locus of control auditors and their intention to report errors and quality of auditors' work. Thus, the third and forth research hypotheses are:

$\mathrm{H}_{3}$ : There is a positive and significant relationship between auditors' locus of control and auditors' intention to report errors.

$\mathrm{H}_{4}$ : Auditors with internal locus of control have more intention to report errors than auditors with external locus of control.

\section{RESEARCH METHODOlOGY}

This research utilizes a survey design where a mail questionnaire will be developed to collect data for the study. The use of mail questionnaire survey is the most suitable method to address the research questions in this study. Since, it is a common approach in business ethic studies and also is appropriate for research question which asking about participant's self-reported beliefs and behaviours [30]. This study combines the use of questionnaire and vignettes design (short, hypothetical cases) like other ethical studies in self-reporting issues in auditing (e.g. [30]-[32]). 


\section{A. Research Instrument}

The research instrument is divided into 3 sections. Section I describes vignettes or scenario which indicates error in financial statements. This part measures auditors' intention to report errors of financial statements. Section II relates to locus of control variable. Locus of control instrument is adapted from [33] based on instrument developed by [34]. This section has 16 items to measure locus of control orientation related to organizational outcomes [34]. Eight items measure "internal" and eight items measure "external" control over work specific issues. Respondents are asked to identify the relationship between outcomes and causes using 5 -point scale. The score range is from 1 (disagree very much) to 5 (agree very much). The minimum score is 16 and the maximum is 96 [34]. Following prior studies, respondents with scores above median are classified as individuals with internal locus of control and those with scores below median are classified as individuals with external locus of control [34]. The instrument's reliability and validity have been deemed acceptable in prior studies (e.g. [28], [33]).

Section III relates to personality type variable. For measuring personality type of auditors, Blumenthal's type A self-rating instrument adapted from [2]. The instrument consists of 38 personality characteristics. Participants are asked to point out the extent to which each personality characteristics defines them. When all responses have been scored, individuals with above the median score are classified as type A personality and those with below the median score are classified as type B personality [35].

\section{B. Sampling}

The population of this study consisted of all practicing auditors in Malaysia that are registered as a member of the Malaysian Institute of Accountant (MIA). However, among all these auditors (MIA members), only audit seniors will be selected in the sample. Audit seniors are in charge of field work, they are located at the client's office for most of the engagement [36]. Therefore, they are more likely to detect errors in client financial information. Reference [37] argue that senior auditors are the foot soldier's and do the maximum work on an audit among the different hierarchical levels and they are exposed to the client the most. Thus, the rationale for choosing audit seniors is based on the argument that reporting errors are usually made by members close to the inner working of an organization and they detected errors more than other levels therefore they are in a position to report detected errors to superior levels (e.g. [31], [38]).

1000 mail survey is distributed among senior auditors who are MIA members with the assistance of the MIA. MIA had prepared the list of respondents (Labels) based on the requirement given by the researcher with the proviso that only MIA members that are currently working as audit senior in audit firms should be selected as respondents. The mail questionnaire administration results in a final usable 174 responses for analysis (17.4\% response rate). Recent studies by [30] and [39] who utilized Institute of Internal Auditors Malaysia (IIA) get $17 \%$ and $18 \%$ response rate respectively. Therefore, the response rate of $17.4 \%$ of this study is justified based on these prior studies.

\section{PRIMIRALITY DATA ANALYSIS}

\section{A. Validity}

Content or Face Validity of the research instrument is checked by conducting pre-test and pilot study. 5 academics that have audit experience are asked to read the research instrument and give their ideas and comments about the questionnaire. For pilot testing, 30 audit seniors who are the member of MIA filled up the questionnaires and answered the pilot test questions. Then, the research instrument is improved based on respondents' comments and recommendations.

\section{B. Reliability}

In terms of reliability, Cronbach's Alpha is checked for all research variables. The results indicate that the Cronbach's Alpha reliability coefficients for all variables are above 0.8 . Generally, reliabilities of less than 0.6 are considered to be poor, those of 0.7 are considered acceptable, those above 0.8 are good, while the closer the reliability coefficient to 1.0 , the better.

\section{Normality and Malticollinearity}

For developing multiple regression models, the distribution of dependent variables must be normal. The analyses on skewness and kurtosis support the normality distribution of the data as the value of skewness fallen in the range of -1 to +1 and the value of kurtosis is in the range of -2 to +2 for all variables. Moreover, normality is checked through the examination of residual statistics and graphical examination of scatter plots and histograms.

In addition, for testing multicollinearity among independent variables, Variance Inflation Factor (VIF) is used. The results show that the VIF scores for all independent variables are below 2 . Therefore, multicollinearity may not be a concern in this research.

\section{MultiPle Regression AnAlyses AND ReseARCH RESULTS}

\begin{tabular}{|c|c|c|c|c|c|}
\hline & B & S.E & $\beta$ & $t$ & sig \\
\hline Constant & 0.03 & 0.29 & & 0.12 & 0.90 \\
\hline Personality Type & 0.90 & 0.16 & 0.36 & 5.61 & $0.00 *$ \\
\hline Locus of Control & 0.90 & 0.15 & 0.38 & 5.93 & $0.00 *$ \\
\hline \multicolumn{6}{|l|}{$R^{2}=0.37$} \\
\hline$F$-Value $=51.739$ & & & & & \\
\hline
\end{tabular}

A standard multiple regression and independent sample t-test are used to investigate the hypothesized relationship between independent variables and dependent variable. Table I represents the results of multiple regression analysis. Based on the results, the linear combination of 2 independent variables significantly predicts auditors' reporting intention, $R^{2}=0.37, F(2,171)=51.739, p \leqslant 0.01$. This model accounts for $37 \%$ of the variance in reporting intention. The $\mathrm{F}$ ratio of 
51.739 is statistically significant at $1 \%$ level. In fact, the regression model appears to be efficient in predicting auditors' reporting intention. A review of the regression coefficients indicates that both personality type and locus of control have positive and significant relationship with auditors' intention to report errors and misstatement. But, the beta weights $(\beta)$ reveal that locus of control has more effect on auditors' reporting intention than personality type.

Table II shows the results of t-test for comparing auditors' intention to report errors between auditors with personality type $\mathrm{A}$ and $\mathrm{B}$ and also auditors with internal and external locus of control.

TABLE II: RESULTS OF T-TEST

\begin{tabular}{rccccc}
\hline & $N$ & Mean & S.D & $t$ & sig \\
\hline Personality Type: & & & & & \\
Type A & 115 & 3.36 & 0.91 & -6.926 & $0.00^{*}$ \\
Type B & 59 & 2.12 & 1.20 & & \\
Locus of Control: & & & & & \\
Internal & 96 & 3.48 & 0.92 & -7.674 & $0.00^{*}$ \\
External & 78 & 2.27 & 1.11 & & \\
\hline
\end{tabular}

Note: *Correlation is significant at the 0.01 level

Based on the results, the difference between two groups (personality type A and personality type B) is significant for reporting intention. The mean for personality type $\mathrm{A}$ is 3.36 which is more than mean of personality type B (2.12) for reporting intention. This result shows that auditors with type A personality have more reporting intention than auditors with type B personality. Moreover, the results show that there is a significant difference between auditors' reporting intention with internal and external locus of control. The mean for internal locus of control is 3.48 which is more than mean of external locus of control (2.27). This results show that auditors with internal locus of control have more intention to report errors than auditors with external locus of control. Based on these results all four research hypotheses are supported.

\section{CONClusion, Limitation AND Future StUdies}

This research investigates the reporting intention of external auditors in Malaysia. Specifically, this study examines the effects of individual factors including personality type and locus of control on auditors' intention to report errors. The results of testing hypotheses support the relationship between personality type and intention and reveal that auditors displaying type A personality have more intention to report the detected errors and they are more likely to behave ethically rather than auditors displaying type $\mathrm{B}$ characteristics. One explanation for this result offers by [18]. They conclude that type A individuals are more ethically oriented than type B individuals. Thus, it is no surprise that type $\mathrm{A}$ auditors have more intention to act ethically and have more intention to report the detected errors. This result is consistent with [40] and [2] who find that auditors with type A personality are less involved in unethical behaviours and act more ethically compare to auditors with type B personality. Reference [12] argue that similar to the results of [41], the positive beta coefficient indicates that participants displaying type $\mathrm{B}$ characteristics are more engaged in unethical behaviours rather than auditors displaying type A characteristics. Although not conclusive, the results of these studies provide some explanations for the reasons that underlie the behaviour of type A and type B auditors surveyed in this study. However, the results of this research are inconsistent with [42], as they find no significant effects of personality type on behavioural intention. One reason is that they used type A instrument in a short form with six questions. Whereas, in this research the completed type A instrument with 38 questions is used.

Locus of control is also predicted to significantly influence auditors' intention to report errors. The results support this relationship and reveal that auditors with internal locus of control have more intention to report the detected errors and they are more likely to behave ethically than auditors with external locus of control characteristics. This result is consistent with [28], [33] and [34]. The results are also consistent with Chiu (2003) who finds that individuals with external locus of control have less intention to report the wrongdoings. His results reveal that auditors with external locus of control are not take responsibility of blowing the whistle, even when they considered whistle blowing ethical, but auditors with internal locus of control have more intention to report wrongdoings. He argues that as individuals with internal locus of control more believe in their own efficiency, they are more motivated to engage in prosocial and ethical behaviours such as reporting wrongdoings or reporting the detected errors.

Several limitations emerge when evaluating the research results. First, the sensitive nature of ethical behavior brings into question the honesty of responses. Second, the most obvious limitation of this research is using self-reported data to determine auditors' intention to report errors. In fact, all data are obtained from one source - the respondents. This may raise concerns about the validity and generalisability of research results.

While this study suggests a new ground in investigating the relationship between individual factors and auditors' intention to report errors in Malaysia, there is still a need to conduct more studies on this topic. For example it is essential to examine the effect of firm and team factors on auditors' intention to report errors. Also, it is suggested to use other methods such as interview and experimental design for investigating the effects of these factors on auditors' behavioral intention.

\section{REFERENCES}

[1] J. T. Morris, "The impact of authentic leadership and ethical organizational culture on auditor behavior," Ph.D. dissertation, University of San Diego, U.S.A, 2009.

[2] M. N. M. Nor, "Auditor stress: antecedents and relationships to audit quality," Ph.D. dissertation, Edith Cowan University, Australia, 2011.

[3] I. Ajzen, "The theory of planned behavior," Organizational Behavior and Human Decision Processes, vol. 50, pp. 179-211, 1991.

[4] H. Paino, Z. Ismail, and M. Smith, "Dysfunctional audit behavior: an exploratory study in Malaysia," Asian Review of Accounting, vol. 18 , no. 2, pp. 162-173, 2010

[5] S. Baotham, "Audit independence, quality, and credibility: effects on reputation and sustainable success of CPAs in Thailand," International Journal of Business Research, vol. 9, no. 1, 2009.

[6] Y. Wang, L. Yu, Z. Zhang, and Y. Zhao, "Engaging audit partner experience and audit quality," Working paper, 2012. 
[7] L. S. Tsui and F. A. Gul, "Auditors' behaviour in an audit conflict situation: a research note on the role of locus of control and ethical reasoning," Accounting, Organization and Society, vol. 21, no. 1, pp. 41-51, 1996.

[8] M. Z. Sanusi, T. M. Iskandar, and M. L. June, "Effects of goal orientation and task complexity on audit judgment performance," Malaysian Accounting Review, vol. 6, no. 2, pp. 123-139, 2010.

[9] N. Harding and K. T. Trotman, "Enhancing professional skepticism via the fraud brianstorming discussion outcomes," Working paper, University of New South Wales, 2011.

[10] T. Libby and L. Thorne, "Auditors' virtue: a qualitative analysis and categorization," Working paper, Wilfrid Laurier University, 2000.

[11] H. Paino, Z. Ismail, and M. Smith, "Dysfunctional audit behavior: an exploratory study in Malaysia," Asian Review of Accounting, vol. 18, no. 2, pp. 162-173, 2010.

[12] L. C. Gundry and G. A. Liyanarachchi, "Time budget pressure auditors' personality type and the incidence of reduced audit quality practices," Pacific Accounting Review, vol. 19, no. 2, pp. 125-152, 2007.

[13] B. D. Kirkcaldy, R. J. Shepard, and A. F. Furnham, "The influence of type A behavior and locus of control upon job satisfaction and occupational health," Personality and Individual Differences, vol. 33, pp. 1361-1371, 2002.

[14] J. Ardenne, S. McManus, and J. Hall, "Designing survey questions on food-related issues question design toolkit based on a theory of behavioral change," Prepared for the Department of Health, National Center for Social Research, 2011

[15] R. K. Chiu, "Ethical judgment and whistle blowing intention: Examining the moderating role of locus of control," Journal of Business Ethics, vol. 43, pp. 65-74, 2003.

[16] S. N. H. M. Zawawi, K. Jusoff, R. A. Rahman, and K. M. Idris, "Behavioral intention for fraudulent reporting behavior using cognitive theory," Asian Social Science, vol. 4, no. 7, pp. 43-47, 2008.

[17] R. T. Fisher, "Role stress, the type A behavior pattern, and external auditor job satisfaction and performance," Behavioral Research in Accounting, vol. 13, pp. 143-170, 2001

[18] J. M. Rayburn and L. G. Rayburn, "Relationship between Machiavellianism and Type A and ethical-orientation," Journal of Business Ethics, vol. 15, pp. 1209-1219, 1996.

[19] K. B. Menk, "The impact of materiality, personality traits, and ethical position on whistle-blowing intentions," Ph.D. dissertation, James Madison University, Harrisonburg, 2011.

[20] C. A. Knight and W. F. Wright, "Characteristics of relatively high-performance auditors," Auditing: A Journal of Practice and Theory, vol. 30, no. 1, pp. 191-206, 2011.

[21] J. B. Rotter, "Internal versus external control of reinforcement: A case history of a variable," American Psychologist, vol. 45, pp. 489-493, 1990.

[22] C. Boone and W. Hendriks, "Top management team diversity and firm performance: moderators of functional-background and locus-of-control diversity," Management Science, vol. 55, no. 2, pp. 165-180, 2009

[23] T. W. H. Ng, K. L. Sorensen, and L. T. Eby, "Locus of control at work: a meta-analysis," Journal of Organizational Behavior, vol. 27, pp. $1057-1087,2006$.

[24] A. J. Kinicki and R. P. Vecchio, "Influences on the quality of supervisor-subordinate relations: the role of time-pressure, organizational commitment, and locus of control," Journal of Organizational Behavior, vol. 15, pp. 75-82, 1994.

[25] H. S. Risser, "Internal and external comments on course evaluations and their relationship to course grades," The Montana Mathematics Enthusiast, vol.7, no. 2-3, pp. 401-412, 2010.

[26] C. Leone and J. Burns, "The measurement of locus of control: assessing more than meets the eye?" The Journal of Psychology, vol. 134, no. 1 , pp. 63-76, 2000.

[27] R. Mowday, R. Steers, and L. Porter, "The measurement of organizational commitment," Journal of Vocational Behavior, vol. 14 pp. 224-247, 1979.

[28] D. Donnelly, J. Quirin, and D. O'Bryan, "Auditor acceptance of dysfunctional behavior: an explanatory model using auditors' personal characteristics," Behavioral Research in Accounting, vol. 15, pp. 87-110, 2003.

[29] L. K. Trevino, "Ethical decision making in organizations: a person-situation interactionist model," Academy of Management Review, vol. 11, pp. 601-617, 1986.

[30] S. A. Ahmad, "Internal auditors and internal whistle-blowing intentions: a study of organizational, individual, situational and demographic factors," Ph.D. dissertation, Edith Cowan University, Western Australia, 2011
[31] N. A. Ghani, J. Galbreath, and R. Evans, "Predicting whistle-blowing intention among supervisors in Malaysia," Journal of Global Management, vol. 3, no. 1, pp. 1-18, 2011

[32] P. A. Alleyne, M. Hudaib, and R. Haniffa, "A model of whistle-blowing intentions among external auditors," in Proc. the Accounting and Finance Association of Australia and New Zealand Conference, 2012.

[33] H. Paino, M. Smith, and Z. Ismail, "Auditor acceptance of dysfunctional behavior: an explanatory model using individual factors," Journal of Applied Accounting Research, vol. 13, no. 1, pp. 3-3, 2012

[34] P. E. Spector, "Development of the work locus of control scale," Journal of Occupational Psychology, vol. 61, pp. 335-340, 1988.

[35] J. A. Blumenthal, "Development of a brief self-report measure of the Type A (coronary prone) behavior pattern," Journal of Psychosomatic Research, vol. 29, no. 3, pp. 265-274, 1985.

[36] D. M. Guy, C. W. Alderman, and A. J. Winters, Auditing, Third ed., Fort Worth. TX: The Dryden Press, 1993.

[37] S. K. Pillalamarri and C. Holm, "The mode of reasoning and context danish evidence of accounting student's moral reasoning abilities in resolving ethical dilemmas related to fraud," presented at the American Accounting Association, Annual Meeting and Conference on Teaching and Learning in Accounting, 2012.

[38] S. E. Kaplan and S. M. Whitecotton, "An examination of auditors' reporting intentions when another auditor is offered client employment," Auditing: A Journal of Practice and Theory, vol. 20, no. 1, pp. 45-63, 2001

[39] Z. Ahmad and D. Taylor, "Commitment to independence by internal auditors: The effects of role ambiguity and role conflict," Managerial Auditing Journal, vol. 24, no. 9, pp. 899-925, 2009.

[40] L. C. Gundry and G. A. Liyanarachchi, "Time budget pressure auditors' personality type and the incidence of reduced audit quality practices," Pacific Accounting Review, vol. 19, no. 2, pp. 125-152, 2007.

[41] C. F. Malone and R. W. Roberts, "Factors associated with the incidence of reduced audit quality behaviors," Auditing: A Journal of Practice and Theory, vol. 15, no. 2, pp. 49-64, 1996.

[42] T. Kelley and L. Margheim, "The impact of time budget pressure, personality, and leadership variables on dysfunctional auditor behavior," Auditing, vol. 9, no. 2, pp. 21-42, 1990.

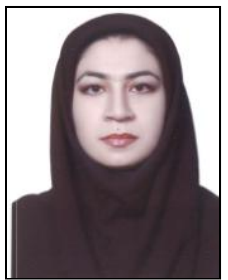

Arezoo Aghaei Chadegani is a Ph.D. candidate of accounting in University Kebangsaan Malaysia (UKM). She was working as an accountatnt in Tuka Transportation Company in 2002 and she was a lecturer in Payame-noor University, University of Applied Science and Technology, Sanaee, Almahdi and feyzoleslam Institutes (Private Universities) from 2007 till 2009. She published some articles about predicting financial distress, ownership structure, and audit quality. Her research interests include audit quality, reporting errors, ethical culture, behavioral intention and financial distress.

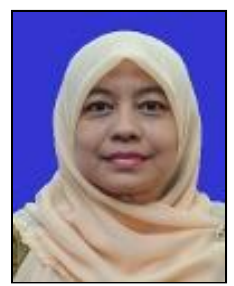

Zakiah Muhammaddun bt Mohamed is the head of the accounting programe, School of Accounting, Faculty of Economics and Management, Universiti Kebangsaan Malaysia. She has produced several books with her most recent titled "Qualitative Research in Accounting: Malaysian Cases" and published articles including teaching cases in ISI and Scopus indexed journals. She is professionally qualified as a certified internal auditor. Her research interests include audit reporting, internal auditing and corporate fraud.

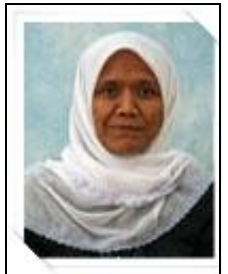

Takiah Mohd Iskandar is a professor in School of Accounting, Faculty of Economics and Management, Universiti Kebangsaan Malaysia. She has produced several books and published articles in ISI and Scopus indexed journals. She is professionally qualified as a CPA (Australia) member and CA (Malaysia). Her research interests include Auditing and Financial Reporting, External Audit, Audit Committee, Board of Directors and Corporate Governance, Auditing and Earnings Management. 